\title{
A Note on some of Hölderlin's Epigrams in English Translation
}

\section{Alfred Behrmann*}

Abstract: The paper examines the epigrams included in Michael Hamburger's translations of Hölderlin's work, focusing on the observance of metrical rules and offering alternatives where they have not been complied with, taking care to change as little as possible.

Keywords: Hölderlin, epigram, prosody, literary translation

In matters of prosody one has to be punctilious, which is not the same as petty or fussy. Careful attention is called for notably in very short poems where the slightest blemish immediately strikes the ear of any connoisseur.

Jean-Paul Jacobs in conversation

Pound's esteem for Yeats ('the greatest living poet in English') did not stop him from improving some of that poet's lines. May one not, then, expect forgiveness if one suggests some changes in the work of so accomplished a translator of German verse into English as Michael Hamburger?

Here is Hölderlin's

Sophokles

Viele versuchten umsonst das Freudigste freudig zu sagen

Hier spricht endlich es mir, hier in der Trauer sich aus.

* Author's address: Alfred Behrmann, Free University Berlin, Ferdinandstraße 22, D-12209 Berlin, Germany; email: lesal.behrmann@gmx.de. 


\section{Sophocles}

Many have tried, but in vain, with joy to express the most joyful;

Here at last, in grave sadness, wholly I find it expressed. ${ }^{1}$

Suggested alternative:

Many have tried in vain to put forth with joy the most joyful;

Here in sadness at last, wholly I find it expressed.

Of the variants proposed only one is essential; it concerns the pentameter: the observance of its specific mark, the clash of two stresses (arses) at the caesura, in the middle of the line:

$$
\text { X́x (x) X́x (x) x́| X́x x ́x x x́ }
$$

In Hamburger's version the first half of the line (hemistich) ends with an unstressed syllable (thesis): [sád] nĕss instead of a stressed one that would clash with wholly. The remedy is easy: at last and sadness change places.

The other variants are put forward for stylistic reasons. They are, in order: (1) the omission of but from the hexameter. It lacks a warrant in the German, and without it the translation has more of the simplicity and even flow of the original. (2) The replacing of express with 'put forth.' It avoids a repetition in close proximity: expressed in the second line. (3) The shifting of with joy towards the end of the verse. It brings joy and joyful more closely together, echoing the German and adding to the contrast with sadness in the next line. (4) Lastly, another omission: that of grave from grave sadness, proposed, again, to keep faith with the straightforwardness of the German. This excision is more difficult to defend than the first. It might be argued that unqualified sadness is too weak to render Trauer, which denotes a deeper sentiment than mere sadness (Traurigkeit). True - so true that other options should be considered. There is 'mourning' - the dictionary equivalent of Trauer - for 'sadness.' It carries the same semantic weight as grave sadness and is, on that score, admissible, as is, for the same reason, 'deep grief,' which would allow adherence to Hamburger's word order: 'Here at last in deep grief...' The question raised by my version as given above is this, Can one admit the objection to unqualified 'sadness' and still prefer the omission of grave? If one does, one opts for style

1 Hölderlin 2004: 108; here are also the following four distichs. Hölderlin's texts in this book (also used in the present pages) are mainly based on Friedrich Beissner's edition (Beissner 1943-1977). 
at the expense of exact semantic equivalence - a dilemma ineluctable in the translation of poems. ${ }^{2}$

Sophocles is one of five distichs forming the second of two groups of epigrams in Hamburger's translation. Surprisingly, all five of their pentameters are faulty; surprisingly because their blemishes are absent (or all but absent) from other distichs: those of the elegies. Arguably, the epigrams belong to an earlier stage of the sixty-years' labour that the author spent on his English versions and lack the benefit of revision bestowed on later work. ${ }^{3}$

It seems worthwhile to look at the other four epigrams in an attempt, not to find fault but to find out what might be done, by a minimum of change, to redress the violation of any of the three rules that govern the formation of correct pentameters. They are: (1) the fixed number of syllables (12 to 14 according to the type of foot - dactyl or trochee - chosen for the first two positions); (2) the obligatory caesura (hephthemimeres) in the middle of the line where two stressed syllables (ictus) clash; and (3) the immutable structure of the line's second half: x́x x x́ x x x́.

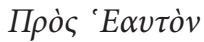

Lern im Leben die Kunst, im Kunstwerk lerne das Leben,

Siehst $d u$ das Eine recht, siehst $d u$ das andere auch.

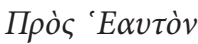

Living, in life, learn your art, in art works learn about living;

If the one you see clearly, aright, likewise the other you'll see.

Living, in life, learn your art, in art works learn about living;

Seeing aright the one, likewise the other you'll see.

2 An impressive example of considerations of form overriding those of 'content' occurs in 'Auden's Last Poem' by Harald Hartung:

No manuscript was found

Of the haiku

Auden is said to have scrapped it

It had two syllables too many.

(Hartung 2010: 24)

3 The five epigrams of the first group (Hölderlin 2004: 61) support this impression: three of their hexameters and one pentameter are too long by one foot. 
Here, in Hamburger's version, the required clash of two stresses at the centre has been observed, but the first hemistich has outgrown its size; instead of the maximum 7 syllables it has 9. This seems easy to right: by dropping clearly, whose lack of a counterpart in the original marks it out for deletion. The trouble is, that even with clearly gone, the hemistich does not pass muster because the metre is disturbed. The cutting results in a sequence of four trochees, i.e. four stresses: If the óne you sée aríght where only three comply with the rule. This again is easy to mend: by replacing the conjunctional clause (If you see...) with a participle construction ('Seeing...').

Der zürnende Dichter

Fürchtet den Dichter nicht, wenn er edel zürnet, sein Buchstab

Tödtet, aber es macht Geister lebendig der Geist.

The Angry Poet

Never fear the poet when nobly he rages; his letter

Kills, but his spirit to spirits gives new vigour, new life.

Never fear the poet when nobly he rages; his letter

Kills, but his spirit imparts vigour to spirits, new life.

There are two things wrong here with the pentameter. The caesura, instead of falling behind the third stress, falls behind the syllable following it; and the second hemistich, whose structure is rigorously fixed ( $\dot{\mathrm{X} x x} \dot{\mathrm{x} x x} \dot{\mathrm{x}})$, is short by one syllable after the first stress. Both faults are easy to mend.

\section{Die Scherzhaften}

Immer spielt ihr und scherzt? ihr müßt! o Freunde! mir geht diß

In die Seele, denn diß müssen Verzweifelte nur.

\section{The Jokers}

Always you trifle and joke? You have to? O friends, how my very

Soul responds to your plight: No one has to but those in despair.

Always you trifle and joke? You m u st? O friends, how it hurts my

Soul, for nobody must, no one but those in despair.

Here, the caesura falls correctly, but the second hemistich is too long by two syllabes (9 instead of 7), which gives it a fourth ictus or arsis: Nó one hás to but thóse in despáir. 
Apart from bringing the pentameter in line with the rules, the change undoes the amplification of Hölderlin's mir geht diß / In die Seele in the translator's my very / Soul responds to your plight. The act of shrinking removes the word plight: a notion linked to the poet's perspective, not the jokers', who seem to be happy enough with their compulsive urge. If Hölderlin trusts the reader to see a plight in it, one might as well leave it at that.

There is another point here that invites reflection. Why, in the English, is the exclamation mark after ihr müßt replaced with a question mark: You have to? Obviously both punctuations intimate the same: the poet's response to the answer he has received from the jokers - his half-incredulous repetition of their words. So strong is the emphasis on müßt that Hölderlin spaced it. His exclamation mark is there to redouble the stress: not a sign of carelessness in the author who forgot to mark the words as a question (a job that is left to the context). The translator mistakenly thought there was something to put right here: another instance supporting the assumption that these epigrams were translated by an author not yet on top of his burgeoning adventure. (Thus he failed to take over the spacing of $m \ddot{u} \beta t$ from his chief source - the Große Stuttgarter Ausgabe - into his German text.) In compliance with my principle of 'minimum change' I retained his question mark.

Wurzel alles Übels

Einig zu seyn, ist göttlich und gut; woher ist die Sucht denn

Unter den Menschen, daß nur Einer und Eines nur sei?

The Root of All Evil

Being at one is godlike and good, but human, too human, the mania

Which insists there is only the One, one country, one truth and one way.

Being at one is godlike and good, but whence among men this

Urge to allow but the One, one in all beings and ways?

Owing to its high degree of condensation and its 'open' semantics - relying on suggestion rather than exact denotation - this last epigram of the group is clearly the hardest to translate, which should arouse some indulgence in the reader who expects a strict translation and instead is given a paraphrase: more interpretation than scrupulous rendering of the text under the restricting conditions of metered speech.

Metric anomalies abound. The trouble starts with a hexameter that isn't one; extra syllables wedged in between the fourth and fifth foot (áll human) blow it up into a heptameter. No less irregular the pentameter. Its first half has 
four feet for the canonical three; the second starts with a supernumerary thesis (one), which deprives the verse of is hallmark, the clash of stresses at the centre, and blurs the symmetry of its structure. A likely objection to the alternative suggested is, that 'Urge' (Trieb, Drang) is too weak a replacement for mania (Sucht), which, of course, is true. Called for, however, was a monosyllable, one that at least comes close to mania in meaning - a debatable choice, admittedly, like any choice between semantic and metric considerations.

What has happened here is obvious. The translator, confronted with two tasks, both formidable and rarely compatible - the rendering of meaning and the preserving of metre -, has tackled the first and all but given up on the second or, at least, allowed himself great liberties in handling it. One sees him trying to make sense of, or rather draw a maximum of explicitness from, a distich highly charged with meaning but meaning left largely implied. His success can best be gauged by the paraphrase test, and Hamburger, to be sure, comes off well in it. I for one can find no fault with the result of his 'unfolding' of the implicit. For what is the One (Einer) and one (Eines) if not one person (who may well be a god) and one way of life postulated as unique and binding norms? The terms - the One, one - are loose enough to suggest a wide range of items such as ruler, ruled, and rules or Hamburger's country, truth, and way, i.e. the political, religious, and social institutions of a society. To specify these facets with any claim to completeness or exactness is neither possible within the narrow bounds of the distich nor covered by the poet's authority. In a letter to his brother Karl of June 4, 1799, the year from which the epigram presumably dates, Hölderlin, speaking of 'people' ('die Menschen') in terms no more specific than those of the epigram, writes: 'Not so much that they are as they are but that they hold what they are to be the only norm ['das Einzige'] and will not admit anything else, that is the evil.' Since the poet kept his statement general, I tried in my suggested version to specify as little as possible ('beings and ways'), unable as I was to avoid specification altogether.

Behind the question, How plausible are Hamburger's specifications of the unspecified? emerges another: Is he, as a translator, entitled to undertake them? By making implications or mere possibilities explicit, he passes from rendering the original in another tongue to its interpretation. Whether this is legitimate or philological abuse has long been debated among theorists of translation. Here is no room for a lengthy discussion of this knotty issue. Only this much should be said, for clarity's sake, with regard to the present case. Certain elements of interpretation are never absent from translation, simply because they are not absent from perception. Anyone who reads with a view to grasping the essence of what he reads interprets, and no two readers reading the same work in the same edition perceive the same in their reading because 
their perceptions are differently oriented and conditioned. Else there would be no squabble over the right way to understand a poem. And a translator is a reader who sets down in a different medium what he perceives in the original what he perceives in it, not what he wants it to say. That is a difference at which we may stop, for there is no evidence of Michael Hamburger's wanting to say a thing that Hölderlin would have refused to acknowledge. ${ }^{4}$

The cardinal problem then, which needs addressing once more, is that of metre. What explains the adherence to a strict pattern, that of the classical distich, vis-à-vis a cavalier treatment of its rules? Was the translator satisfied, at least initially, with a relaxed view of metrical minutiae? It seems fit to hold his practice against the background of his declared intentions. In his Preface (of 2003) he writes:

I had decided that I must retain his [Hölderlin's] adaptation of classical forms in my versions, much more refractory though these forms have proved in English $[\ldots]$ than in German [...]. ${ }^{5}[\mathrm{M}]$ any of my versions could have been made to run more smoothly and acceptably for English-language ears; but the exoticism of these metres $[\ldots]$ struck me as indispensable in his case. ${ }^{6}$

With the modesty so characteristic of this fine man he goes on to say:

It's enough for me if these versions of mine remain accessories to the originals that face them in this book - or substitutes, as close to these as I could make them not only in sense [...] but in movement, structure, breath and tone, for readers with no access at all to the German texts. ${ }^{7}$

4 That translation implies interpretation (in the sense outlined) suggests affinity between their purposes. So much of what Peter Szondi says about the latter applies to the former that mere quotation will bear out the analogy:

'No commentary on a poem, no critical examination of its style may aim at a description of the poem that could be considered by itself. [...] This is obvious particularly in the extreme case of the hermetic poem. Here interpretations are keys. But it cannot be their business to face the poem with its deciphered image. For although the hermetic poem, too, wants to be understood and often cannot be understood without a key, it must be understood, in the act of deciphering, as an encyphered poem since only as such is it the poem that it is. It is a lock that time after time snaps shut; its elucidation must not attempt to break it open' (Szondi 1970: 12).

5 Hölderlin 2004.

6 Hölderlin 2004.

7 Hölderlin 2004. 
Giving equal weight to both these aspects, he conforms to the basic principle of all good translation, notably that of poetry in classical metres.

I would like this present Note to be seen as an exposition of, or rather, in view of its brevity, a glimpse into, the jumble of quandaries awaiting the grappler with this intriguing and off-putting business. The poems and translations quoted, however few and short, and their limited technical discussion may yet lead on to some reflections on poetry, which includes translation if the translator aims at poetry, not a crib, digest, or paraphrase.

An author who wants to write a poem in strict form such as elegiac distichs or French alexandrines has to rely on other promptings than those of emotion, intuition, and spontaneity. Once he has accepted the rules, writes Valéry, he

can no longer say everything; and in order to say anything, it is no longer enough to conceive it strongly, to be full of it and drunk with it, nor to give off at some mystic moment a figure which has been almost completed in our absence. [...] [H] e must labor [..., ] pursue words that do not always exist and chimeric coincidences [...]. (Valéry 1958: 16)

He has to hope, that is, for the slender chance of finding words that answer different, mutually independent requirements: semantic, grammatical, metric, rhythmic, stylistic, phonetic, etc. ${ }^{8}$ More often than not the sought-for qualities, complete in an ideal word, are not found together in a real word, and the poet, having to make the best of it, determines how many and which of these 'should-be's' are de rigueur.'

8 A concrete example is furnished by Valéry:

'The poet in search of a word that shall be:

feminine

disyllabic

containing $\mathrm{p}$ or $\mathrm{f}$

ending in a mute syllable

synonym of fracture, disruption

and not learned, not rare -

6 requirements - at least.

Syntax, music, prosody, sense, and sensitivity.

(Valéry 1993: 196 f)

9 How much the author's plight is a poetic plight becomes apparent where no constraints of metre or rhyme impinge on his work: in a prose translation of poetry. Their non-interference is bought at the price of their non-co-operation, and that is a high price. In a conversation about Joachim Wohlleben's prose translation of Hafiz's poems (Hafiz 2004) Michael Hamburger placed that undertaking at the opposite end to his own on the scale of modes available to translators. What else should one expect of a poet? 
The translator, too, is challenged by this ever-present dilemma. Aware that he cannot furnish a complete equivalent of the text before him, he sets up an order of importance among its features so as to mark out the least dispensable one(s) for preservation. Here exactly lies the crux of both the translator's and the translator's critic's job, for there is no unquestioned criterion for correct priorities among demands, often jarring and irreconcilable, fixed for translation by diverse authorities. And more than that, conflicting claims are not just a matter for lawgiving schools, each with its own set of ideals and abstract tenets: they are acutely felt by the individual translator who has qualms about his decision in this case or that, who sometimes revokes it and often admits the justness of objections raised (or to be raised) to his choice, even advancing them in occasional footnotes.

I hope that in the light of these last remarks the alternatives to some of the text in Michael Hamburger's translation will be seen for what they are: suggestions put forward, tentatively, for consideration. He was too generous a person and, as his frequent revisions attest, too much aware of the precarious nature of translation, to take them for anything else. As he wrote in his preface to the Third Edition (1989): ${ }^{10}$ "no translation, as such, can be definitive." ${ }^{11}$

It may not be amiss to cast a glance at those other epigrams in Michael Hamburger's translation whose shape gives rise to critical reflection. They are:

\section{Guter Rath}

Hast du Verstand und ein Herz, so zeige nur eines von beiden,

Beides verdammen sie dir, zeigest du beides zugleich.

\section{Good Advice}

You've a head and a heart? Reveal only one of them, I say;

If you reveal both at once, doubly they'll damn you, for both..$^{12}$

You've a head and a heart? Take care to show one of them only;

If you reveal both at once, doubly they'll damn you, for both.

10 Hölderlin 2004.

11 In other words, a translation can be definitive only as the work of an individual author who declares it his ultimate version since nothing that he could do to it would be an improvement.

12 Hölderlin 2004. 
There's something wrong here with Hamburger's hexameter: not a technical fault but one of emphasis. Not only does he introduce an $I$ into it that is absent from the German, he loads it with a semantic weight, or should one say he allows it to attract that weight, owing to the impossibility to leave it unstressed: only as an arsis can it support the hexameter's final formula: the adonian ( $\mathbf{x} \quad \mathrm{x}$ $\mathrm{x}$ x́ $\mathrm{x}$ ). The proposed alternative leaves the main stress on 'one', unchallenged by another stress, as in the German. I am still not happy with this amendment. It pushes the word 'show' into a thesis-position for which it is somewhat too heavy so that the reader (at a first reading) may put the same stress on it as on 'one' and so upset the metre. To avoid this pitfall, the reader needs a clear conception of the line's prosodic build-up. Relying on such a reader is the weak excuse for acquiescing in my makeshift version.

Wondering what may account for the translator's introduction of the 'poetic I' in his version, one finds a hint in a note of Friedrich Beissner's: "It is not improbable that this epigram, like "Die Vortreflichen" and 'Die beschreibende Poësie" [...], has arisen from the deep annoyance at Schillers's renewed rejection of [Hölderlin's] poems "Diotima" and "An die guten Rathgeber" In his letter of November 24, 1796 Schiller had wisely suggested to eschew philosophical topics, i.e. not to show reason in lyrical poems and to keep close to the sensual world, faithfully reporting the given fact' (Beissner 1943-1977: 541). However that may be, Hölderlin has chosen to keep his ' $\mathrm{I}$ ' out of his verses, a decision that should be respected.

\section{Die Vortreflichen}

Lieben Brüder! versucht es nur nicht, vortreflich zu werden Ehrt das Schiksaal und tragts, Stümper auf Erden zu seyn

Denn ist Einmal der Kopf voran, so folget der Schweif auch Und die klassische Zeit deutscher Poëten ist aus.

The Excellent

Dearest brothers, whatever you do, never try to be excellent writers; Honour fate, and accept that it's human to bungle your trade.

For if once the head ventures forth, the tail will certainly follow, And our classical age, Germans, is over for good.

Dearest brothers, don't ever strive to be excellent writers; Honour fate and accept bungling your trade as your lot: Once the head ventures forth, the tail will certainly follow, And our classical age, Germans, is over for good. 
The purport of this double distich, though not expressly stated, is clear; the reader arrives at it by conclusion. ${ }^{13}$ There are writers whose generality cannot hope to achieve distinction by mastering their craft. That is left to the head those possessed of genius - whom the tail of adherents will follow, and that singular event will seal the age of classical German poetry. (Prophetic words.)

The flaws in Hamburger's version: both hexameters are really heptameters; likewise, the first pentameter's second half is too long by one foot. In all three cases the excessive length is easy to check by ridding the lines of dispensable matter.

Die beschreibende Poësie

Wißt! Apoll ist der Gott der Zeitungsschreiber geworden

Und sein Mann ist, wer ihm treulich das Factum erzählt.

Descriptive Poetry

Latest news: Apollo's become the god of journalists, press men, And his blue-eyed boy he who reports all the facts.

Latest news: Apollo's become the journalists' god now, And his blue-eyed boy he who reports all the facts.

Here, too, the English first line has grown into a heptameter - the most frequent departure from the metric norm in Hamburger's versions: a fact that seems to confirm the surmise that the epigrams went into English at an early stage of the translator's practice and were left to stand as they had emerged from a phase of trial and experimentation.

|II

Modern-language verse in ancient metres attracts scant attention, even from philologists including those that go by the name of prosodists. Small wonder at a time when nobody cares to venture so much as a definition of this mysterious thing, a verse.

13 Of several annotated editions I looked up, none devotes a separate commentary to this epigram; only two refer to a different entry that mentions it in passing. Obviously, it is not thought to need explaining. Cf. Schmidt 1969: 305; Lüders 1989: 122. 
Here, the rendering of classical distichs in present-day English could be no more than adumbrated, with attention focused on the observance of the most basic rules of the metric pattern. I conclude by hinting at one or two of the features that were left undiscussed but require attention in any closer inspection of the matter.

There are problems inherent in the substitution of stress (weight) for length (duration) in the build-up of the verse line, which involves the replacing of most ancient spondees $(-\dot{-})$ with modern trochees $(\dot{\mathrm{x}} \mathrm{x})$, or the position of varying caesuras as a means of shaping the verses' rhythmic profile.

In his preface quoted above Michael Hamburger speaks of the much stronger resistence to the adaptation of classical forms in English than in German. It may be partly explained by an abundance of monosyllables and other short words in English not to be found in German. Now very short words, even stressed ones, are easier to put into a thesis-position where they hold their own against the arses in their neighbourhood than are unwieldier ones - something to be observed in Shakespeare's blank verse, a flexible form adaptable to a variety of stylistic modes, admitting a fair amount of freedom for the interplay of metre and rhythm, and allowing almost any deviation from the abstract scheme ${ }^{14}$ so long as this scheme is not lost in the listener's ear.

There is little affinity between this freedom and the more rigid pattern of classical forms, whose contours have to stand out more sharply and steadily if they are not to be blurred by too much looseness (brought on, for instance, by extra syllables or entire feet).

A transfer of the former - the standard, as it were, in English - to the latter is fraught with hazard; it may easily produce an uncomfortable feeling in English ears as when they hear a line like this from a distich in Hamburger's English:

You've a head and a heart? Reveal only one of them, I say

where and, in thesis-position, bears a heavier stress than the surrounding arses, head and heart. Together with the colloquial contraction You've at the beginning and the somewhat precarious I towards the end, this trait explains what the translator means by a different version that 'could have been made to run more smoothly and acceptably for English-language ears' than the strict one he chose.

14 Such as stress shift (anaclasis), (multiple) stress clash, disyllabic theses, or hypermetric and missing syllables. 
So much about the epigrams, a tiny section of the translator's imposing work. To do justice to his achievement requires a comprehensive and detailed examination of its entire body. It would be a meritorious undertaking not only as a tribute to the translator but equally as an elucidation of Hölderlin's poetry through the prism of a different linguistic medium, for nothing demands more minute attention to a poet's craft than rewriting his lines in another tongue and in a metre that exacts utmost precision and economy, while expected to show no signs of constraint. Hölderlin excels in his mastery of the craft, and translation serves to demonstrate that excellence by revealing the limited success at trying to equal it in a foreign version.

\section{References}

Beissner, Friedrich (ed.) 1943-1977. Hölderlin. Sämtliche Werke (Große Stuttgarter Ausgabe). Stuttgart: W. Kohlhammer.

Hafiz 2004. Die Ghaselen des Hafiz. Neu in deutsche Prosa übersetzt, mit Einleitung und Lesehilfen von Joachim Wohlleben. Würzburg: Königshausen \& Neumann.

Hölderlin, Friedrich 2004. Poems and Fragments. Translated by Michael Hamburger. Fourth bilingual edition with a preface, introduction and notes. London: Anvil Press Poetry.

Hartung, Harald 2010. Wintermalerei. Gedichte. Göttingen: Wallstein.

Lüders, Detlev (ed.) 1989. Friedrich Hölderlin. Sämtliche Gedichte. Vol. 2. Wiesbaden: AULA-Verlag.

Schmidt, Jochen (ed.) 1969. Friedrich Hölderlin. Gedichte. Frankfurt a. M.: Insel Verlag.

Szondi, Peter 1970. Hölderlin-Studien. Mit einem Traktat über philologische Erkenntnis. Frankfurt a. M.: Suhrkamp.

Valéry, Paul 1958. The Art of Poetry. Transl. by Denise Folliot. With an Introduction by T.S. Eliot. In: Mathews, Jackson (ed.), The Collected Works of Paul Valéry. Vol. 7. London: Routledge \& Kegan Paul.

Valéry, Paul 1993. Cahiers/Hefte. Ed. by Hartmut Köhler and Jürgen SchmidtRadefeldt. Vol. 6. Frankfurt a. M.: S. Fischer. 